\title{
Analysis of Radiological Impacts to Terrestrial Biota in Support of Environmental Assessment for Use of DOE-Owned High-Assay Low-Enriched Uranium Stored at Idaho National Laboratory
}

Marilyn J. Case, Douglas Halford

October 2018

The INL is a U.S. Department of Energy National Laboratory operated by Battelle Energy Alliance

Idaho National Laboratory 


\title{
Analysis of Radiological Impacts to Terrestrial Biota in Support of Environmental Assessment for Use of DOE-Owned High-Assay Low-Enriched Uranium Stored at Idaho National Laboratory
}

\author{
Marilyn J. Case, Douglas Halford
}

October 2018

Idaho National Laboratory Idaho Falls, Idaho 83415

http://www.inl.gov

Prepared for the

U.S. Department of Energy

Under DOE Idaho Operations Office

Contract DE-AC07-05ID14517 


\section{Analysis of Radiological Impacts to Terrestrial Biota in Support of Environmental Assessment for Use of DOE- Owned High-Assay Low- Enriched Uranium Stored at Idaho National Laboratory}

Document VFS-ID-ESER-NEPA-044

Revision 1

October 27, 2018

Marilyn J Case

Douglas Halford 


\section{Analysis of Radiological Impacts to Terrestrial Biota in Support of Environmental Assessment for Use of DOE-Owned High-Assay Low- Enriched Uranium Stored at Idaho National Laboratory}

\subsection{Purpose}

There are many species of plants and animals (biota) on the INL Site and facilities such as INTEC and MFC have surrounding habitat supporting resident plant and animal populations. Consequently, radionuclide releases from the HALEU processing facilities could pose a potential radiological impact to nearby flora and fauna populations. Therefore, the RESRAD-BIOTA (Version 1.8) computer code (http://resrad.evs.anl.gov/codes/resrad-biota/) was used to assess the impact of radiation exposures to terrestrial biota resulting from soil contaminated by airborne releases from the HALEU processing facilities proposed for the INTEC and/or MFC. The contaminated soil subsequently results in contamination in air and in different food sources used by biota. Both external radiation and internal radiation are considered in the dose evaluation.

\subsection{Scope}

A graded approach that consists of three tiers of analysis is implemented in the RESRAD-BIOTA code. The first step in the graded approach uses conservative default assumptions and maximum values for all currently available data. This general screening level (Level 1 in RESRAD-Biota) provides generic limiting concentrations of radionuclides in environmental media, termed "Biota Concentration Guides." Each biota concentration guide is the environmental concentration of a given radionuclide in soil or water that, under the assumptions of the model, would result in a dose rate less than $1 \mathrm{rad} / \mathrm{d}(10 \mathrm{mGy} / \mathrm{d})$ to aquatic animals or terrestrial plants or $0.1 \mathrm{rad} / \mathrm{d}(1 \mathrm{mGy} / \mathrm{d})$ to terrestrial animals. If the sum of the measured maximum environmental concentrations divided by the biota concentration guides (the combined sum of fractions) is less than one, no negative impact to plant or animal populations is expected. No doses are calculated unless the screening process indicates a more detailed analysis is necessary. Failure at this initial screening step does not necessarily imply harm to organism populations. Instead, it is an indication that more realistic model assumptions may be necessary.

In the case of the potential HALEU releases, the impact on terrestrial plants and animals were assessed assuming that soil outside of the facility fences will become contaminated from airborne releases during HALEU processing. To conduct the analysis, radionuclide concentrations in soil were estimated at locations of maximum deposition outside of the facility fences for Alternatives $1 \mathrm{a}$ and $1 \mathrm{~b}$. For Alternative 1a, it was assumed that deposition would occur for a period of two years as HALEU feed is processed at two facilities at MFC at a rate of $5000 \mathrm{~kg}$ per year. For Alternative $1 \mathrm{~b}$, it was assumed that half of the total HALEU material would be processed at a facility at MFC, while half would be processed at a facility at INTEC. In the Alternative $1 \mathrm{~b}$ case, $2500 \mathrm{~kg}$ would be processed at each facility (MFC and INTEC) per year over a two-year time period. 


\subsection{Methods}

The potential radionuclide concentrations in surface soils around the INTEC and MFC for each alternative were calculated using radionuclide-specific deposition rates modeled by the CAP88-PC computer code (https://www.epa.gov/radiation/cap-88-pc) and radionuclide transport pathway constants. Figure 1 illustrates the pathways modelled.

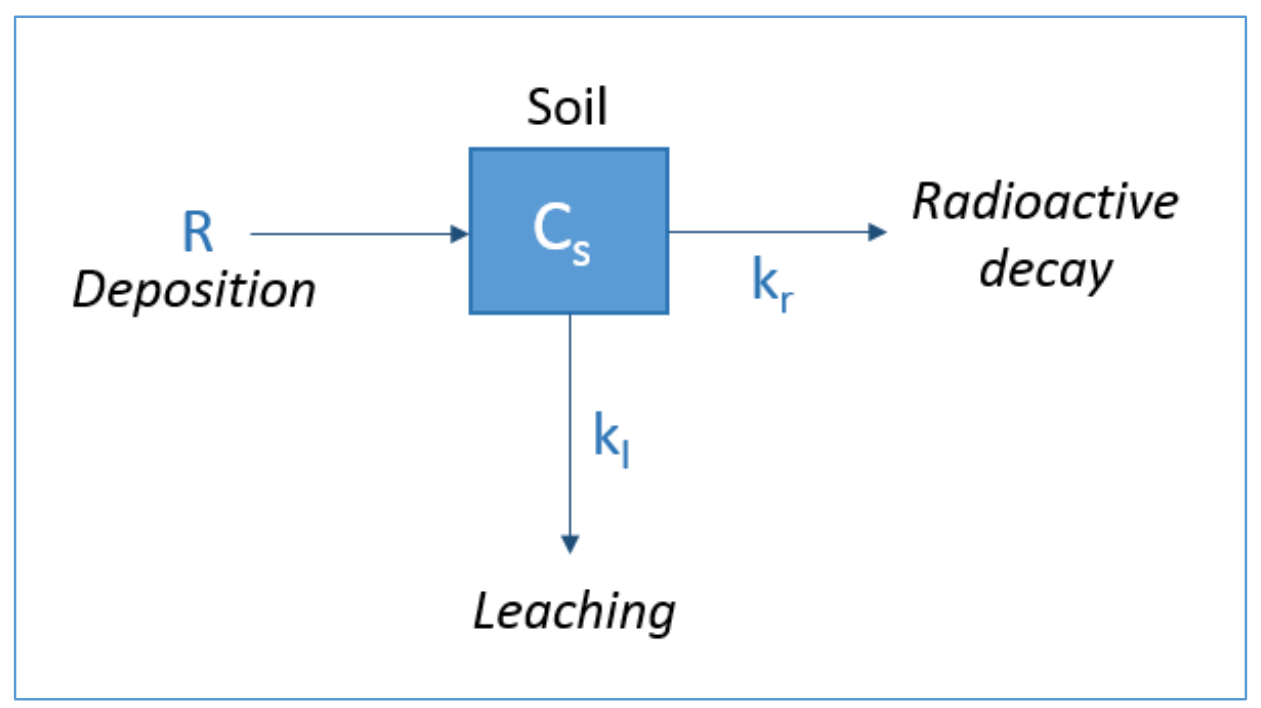

Figure 1. Radionuclide transport pathways in INL surface soil.

The concentration of each radionuclide in soil can be written as

$$
C_{S}=\frac{R}{k_{r}+k_{l}}\left[1-e^{-\left(k_{r}+k_{l}\right) t}\right]
$$

where

$$
\begin{aligned}
& \mathrm{C}_{\mathrm{s}}=\text { concentration in soil surface }\left(\mathrm{pCi} / \mathrm{cm}^{2}\right) \\
& \mathrm{R}=\text { ground deposition rate }\left(\mathrm{pCi} / \mathrm{cm}^{2} / \mathrm{yr}\right) \\
& \mathrm{k}_{\mathrm{r}}=\text { radioactive decay rate constant }\left(\mathrm{yr}^{-1}\right) \\
& \mathrm{k}_{\mathrm{l}}=\text { leach rate constant }\left(\mathrm{yr}^{-1}\right) \\
& \mathrm{t}=\text { time }(\mathrm{yr})(2 \text { years })
\end{aligned}
$$

The ground deposition rates were estimated with CAP-88 PC (Version 4) by the INL Contractor using the HALEU feedstock source terms. The maximum results are shown in Table 1 . The table does not include any daughter products of the radionuclides modelled because:

1. The default internal dose conversion factors used in RESRAD-BIOTA calculations of BCGs include the contribution from build-up of progeny with half-lives less than 100 years.

2. Some of the radionuclides - including Cs-137, Sr-90, Np-237, U-235, and U-238 - have radioactive decay products that are sufficiently short-lived that the decay products are assumed to be in 
Table 1. Maximum ground deposition rates estimated using CAP-88 PC (Version 4) at locations of maximum modelled deposition.

\begin{tabular}{|c|c|c|}
\hline \multirow[b]{2}{*}{ Radionuclide } & \multicolumn{2}{|c|}{ Maximum Ground Deposition Rate $\left(\mathrm{pCi} / \mathrm{cm}^{2} / \mathrm{s}\right)$} \\
\hline & MFC (Alternative $1 a)^{a}$ & INTEC (Alternative $1 \mathrm{~b})^{\mathrm{b}}$ \\
\hline Am-241 & $3.88 \mathrm{E}-01$ & $2.68 \mathrm{E}-01$ \\
\hline Ce-144 & $1.85 \mathrm{E}-04$ & 1.27E-04 \\
\hline Co-60 & $5.06 \mathrm{E}-05$ & 3.49E-05 \\
\hline Cs-134 & 4.35E-02 & 3.00E-02 \\
\hline Cs-135 & $5.69 \mathrm{E}-03$ & $3.92 \mathrm{E}-03$ \\
\hline Cs-137 & $1.26 \mathrm{E}+00$ & $8.72 \mathrm{E}-01$ \\
\hline Eu-154 & $1.02 \mathrm{E}-01$ & 7.03E-02 \\
\hline Eu-155 & $1.72 \mathrm{E}-01$ & $1.18 \mathrm{E}-01$ \\
\hline Mn-54 & $2.16 \mathrm{E}-02$ & $1.49 \mathrm{E}-02$ \\
\hline Np-237 & $2.22 \mathrm{E}-05$ & $1.53 \mathrm{E}-05$ \\
\hline Pu-239 & $9.64 \mathrm{E}-03$ & 6.64E-03 \\
\hline Pu-240 & $9.42 \mathrm{E}-04$ & $6.49 \mathrm{E}-04$ \\
\hline Sb-125 & $1.56 \mathrm{E}-01$ & 1.07E-01 \\
\hline Sr-90 & $3.89 \mathrm{E}+00$ & $2.68 \mathrm{E}+00$ \\
\hline Tc-99 & $3.46 E-09$ & 2.39E-09 \\
\hline$U-232$ & 2.01E-04 & 1.38E-04 \\
\hline U-233 & $5.62 E-06$ & 3.87E-06 \\
\hline U-234 & $1.81 \mathrm{E}-02$ & $1.25 \mathrm{E}-02$ \\
\hline U-235 & 7.61E-04 & $5.24 \mathrm{E}-04$ \\
\hline U-236 & $6.13 E-04$ & $4.23 \mathrm{E}-04$ \\
\hline U-237 & 4.44E-07 & 3.06E-07 \\
\hline U-238 & $4.88 \mathrm{E}-04$ & 3.37E-04 \\
\hline \multicolumn{3}{|c|}{$\begin{array}{l}\text { a. For Alternative } 1 \mathrm{a} \text { it is assumed that } 5000 \mathrm{~kg} \text { of HALEU feed will } \\
\text { be processed per year at MFC. The maximum rates occur at a } \\
\text { location } 200 \mathrm{~m} \text { northeast of the facility. } \\
\text { b. For Alternative } 1 \mathrm{~b} \text { it is assumed that } 2500 \mathrm{~kg} \text { of HALEU feed will } \\
\text { be processed per year at each of two areas (MFC and INTEC). In } \\
\text { this case, the maximum ground deposition rates were } \\
\text { determined to result from releases from INTEC at a location } 200 \\
\text { m northeast of the facility. }\end{array}$} \\
\hline
\end{tabular}

secular equilibrium with the parent radionuclide in each environmental medium. For these radionuclides, the external dose coefficients are the sum of the values for the parent and its short-lived decay products, taking into account the branching fractions in the decay of the parent, and are used in the derivation of the BCGs presented in the RESRAD-BIOTA output.

The radioactive decay rate constant is defined as

$$
k_{r}=\frac{\ln 2}{T_{1 / 2}}
$$


where

$$
T_{1 / 2}=\text { radionuclide half-life }(\mathrm{yr}) \text {. }
$$

The radionuclide half-lives and radioactive decay constants used in this analysis are shown in Table 2 .

Table 2. Radionuclides of interest with half-lives and radiation decay constants.

\begin{tabular}{|c|c|c|}
\hline Radionuclide & Half-life (yr) & $K_{r}\left(y r^{-1}\right)$ \\
\hline Am-241 & $4.33 \mathrm{E}+02$ & 1.60E-03 \\
\hline Ce-144 & 7.80E-01 & 8.89E-01 \\
\hline Co-60 & $5.27 \mathrm{E}+00$ & $1.31 \mathrm{E}-01$ \\
\hline Cs-134 & $2.07 E+00$ & 3.36E-01 \\
\hline Cs-135 & $2.30 E+06$ & $3.01 \mathrm{E}-07$ \\
\hline Cs-137 & $3.01 \mathrm{E}+01$ & $2.30 \mathrm{E}-02$ \\
\hline Eu-154 & $8.60 E+00$ & 8.06E-02 \\
\hline Eu-155 & $4.75 E+00$ & $1.46 \mathrm{E}-01$ \\
\hline$M n-54$ & $8.55 E-01$ & 8.11E-01 \\
\hline $\mathrm{Np}-237$ & $2.14 \mathrm{E}+05$ & 3.24E-06 \\
\hline Pu-239 & $2.41 E+04$ & 2.87E-05 \\
\hline Pu-240 & $6.56 E+03$ & 1.06E-04 \\
\hline Sb-125 & $2.76 \mathrm{E}+00$ & $2.51 \mathrm{E}-01$ \\
\hline Sr-90 & $2.88 \mathrm{E}+01$ & $2.40 \mathrm{E}-02$ \\
\hline Tc-99 & $2.11 E+05$ & $3.28 \mathrm{E}-06$ \\
\hline U-232 & $6.89 \mathrm{E}+01$ & $1.01 \mathrm{E}-02$ \\
\hline U-233 & $1.59 \mathrm{E}+05$ & 4.35E-06 \\
\hline U-234 & $2.46 \mathrm{E}+05$ & $2.82 \mathrm{E}-06$ \\
\hline U-235 & $7.04 \mathrm{E}+08$ & $9.85 \mathrm{E}-10$ \\
\hline U-236 & $2.34 \mathrm{E}+07$ & 2.96E-08 \\
\hline U-237 & $1.85 \mathrm{E}-02$ & $3.75 \mathrm{E}+01$ \\
\hline U-238 & 4.47E+09 & $1.55 \mathrm{E}-10$ \\
\hline
\end{tabular}

The leach rate constant is

$$
k_{l}=\frac{I}{T \Theta R_{d}}
$$

where

$$
\begin{aligned}
& I=\text { infiltration rate }(\mathrm{cm} / \mathrm{yr})(1 \mathrm{~cm} / \mathrm{yr}) \\
& T=\text { thickness of surface soil }(\mathrm{cm})(5 \mathrm{~cm}) \\
& \Theta=\text { moisture content (unitless) }(0.3) \\
& R_{d}=\text { retardation factor (unitless). }
\end{aligned}
$$

The retardation factor is defined as 


$$
R_{d}=1+\frac{\rho_{b}}{\Theta} K_{d}
$$

where

$$
\begin{aligned}
& \rho_{b}=\text { bulk density }\left(\mathrm{g} / \mathrm{cm}^{3}\right)\left(1.5 \mathrm{~g} / \mathrm{cm}^{3}\right) \\
& \Theta=\text { moisture content (unitless) }(0.3) \\
& \mathrm{K}_{\mathrm{d}}=\text { distribution coefficient }\left(\mathrm{cm}^{3} / \mathrm{g}\right) .
\end{aligned}
$$

Distribution coefficients for the INL Site were provided by the INL Contractor and are presented, along with estimated values for $R_{d}$ and $K_{1}$, in Table 3.

Table 3. Values for radionuclide-specific distribution coefficients, retardation factors, and leach rate constants.

\begin{tabular}{|llll|}
\hline Radionuclide & $\mathrm{K}_{\mathrm{d}}$ & $\mathrm{R}_{\mathrm{d}}$ & $\mathrm{K}_{\mathrm{I}}$ \\
\hline Am-241 & 340 & 1701 & $3.92 \mathrm{E}-04$ \\
Ce-144 & 500 & 2501 & $2.67 \mathrm{E}-04$ \\
Co-60 & 10 & 51 & $1.31 \mathrm{E}-02$ \\
Cs-134 & 500 & 2501 & $2.67 \mathrm{E}-04$ \\
Cs-135 & 500 & 2501 & $2.67 \mathrm{E}-04$ \\
Cs-137 & 500 & 2501 & $2.67 \mathrm{E}-04$ \\
Eu-154 & 340 & 1701 & $3.92 \mathrm{E}-04$ \\
Eu-155 & 340 & 1701 & $3.92 \mathrm{E}-04$ \\
Mn-54 & 50 & 251 & $2.66 \mathrm{E}-03$ \\
Np 237 & 18 & 91 & $7.33 \mathrm{E}-03$ \\
Pu 239 & 1480 & 7401 & $9.01 \mathrm{E}-05$ \\
Pu 240 & 1480 & 7401 & $9.01 \mathrm{E}-05$ \\
Sb-125 & 50 & 251 & $2.66 \mathrm{E}-03$ \\
Sr-90 & 24 & 121 & $5.51 \mathrm{E}-03$ \\
Tc-99 & 0.2 & 2 & $3.33 \mathrm{E}-01$ \\
U-232 & 10 & 51 & $1.31 \mathrm{E}-02$ \\
U-233 & 10 & 51 & $1.31 \mathrm{E}-02$ \\
U-234 & 10 & 51 & $1.31 \mathrm{E}-02$ \\
U-235 & 10 & 51 & $1.31 \mathrm{E}-02$ \\
U-236 & 10 & 51 & $1.31 \mathrm{E}-02$ \\
U-237 & 10 & 51 & $1.31 \mathrm{E}-02$ \\
U-238 & 10 & 51 & $1.31 \mathrm{E}-02$ \\
\hline
\end{tabular}

Using equation 1 and the data in Tables 1 through 3, the radionuclide concentrations in surface soil at locations of maximum deposition were estimated (Table 4). The soil depth $(5 \mathrm{~cm})$ and density $(1.5$ $\mathrm{g} / \mathrm{cm}^{3}$ ) were used to convert the soil concentrations from $\mathrm{pCi} / \mathrm{cm}^{2}$ to $\mathrm{pCi} / \mathrm{g}$. 
Table 4. Radionuclide concentrations in soil at locations of maximum depositions after two years of emissions from MFC and INTEC.

\begin{tabular}{|c|c|c|c|c|}
\hline \multirow[b]{2}{*}{ Radionuclides } & \multicolumn{2}{|c|}{ MFC } & \multicolumn{2}{|c|}{ INTEC } \\
\hline & $\mathrm{pCi} / \mathrm{cm}^{2}$ & $\mathrm{pCi} / \mathrm{g}^{\mathrm{a}}$ & $\mathrm{pCi} / \mathrm{cm}^{2}$ & $\mathrm{pCi} / \mathrm{g}^{\mathrm{a}}$ \\
\hline Am-241 & $2.91 \mathrm{E}+00$ & $3.88 \mathrm{E}-01$ & $2.01 \mathrm{E}+00$ & $2.68 \mathrm{E}-01$ \\
\hline Ce-144 & $1.39 \mathrm{E}-03$ & $1.85 \mathrm{E}-04$ & $9.56 \mathrm{E}-04$ & $1.27 \mathrm{E}-04$ \\
\hline Co-60 & $3.79 \mathrm{E}-04$ & $5.06 \mathrm{E}-05$ & $2.61 \mathrm{E}-04$ & $3.49 E-05$ \\
\hline Cs-134 & $3.26 \mathrm{E}-01$ & 4.35E-02 & $2.25 \mathrm{E}-01$ & $3.00 \mathrm{E}-02$ \\
\hline Cs-135 & $4.27 \mathrm{E}-02$ & 5.69E-03 & 2.94E-02 & $3.92 \mathrm{E}-03$ \\
\hline Cs-137 & $9.46 \mathrm{E}+00$ & $1.26 \mathrm{E}+00$ & $6.54 \mathrm{E}+00$ & 8.72E-01 \\
\hline Eu-154 & $7.64 \mathrm{E}-01$ & $1.02 \mathrm{E}-01$ & $5.27 \mathrm{E}-01$ & 7.03E-02 \\
\hline Eu-155 & $1.29 \mathrm{E}+00$ & $1.72 \mathrm{E}-01$ & 8.87E-01 & $1.18 \mathrm{E}-01$ \\
\hline$M n-54$ & $1.62 \mathrm{E}-01$ & $2.16 \mathrm{E}-02$ & $1.12 \mathrm{E}-01$ & $1.49 \mathrm{E}-02$ \\
\hline Np 237 & $1.67 \mathrm{E}-04$ & $2.22 \mathrm{E}-05$ & $1.15 \mathrm{E}-04$ & $1.53 \mathrm{E}-05$ \\
\hline Pu 239 & $7.23 \mathrm{E}-02$ & $9.64 \mathrm{E}-03$ & $4.98 \mathrm{E}-02$ & $6.64 \mathrm{E}-03$ \\
\hline Pu 240 & 7.07E-03 & $9.42 E-04$ & 4.87E-03 & $6.49 \mathrm{E}-04$ \\
\hline Sb-125 & $1.17 \mathrm{E}+00$ & $1.56 \mathrm{E}-01$ & $8.02 E-01$ & 1.07E-01 \\
\hline Sr-90 & $2.92 \mathrm{E}+01$ & $3.89 E+00$ & $2.01 \mathrm{E}+01$ & $2.68 \mathrm{E}+00$ \\
\hline Tc-99 & $2.60 \mathrm{E}-08$ & $3.46 \mathrm{E}-09$ & $1.79 \mathrm{E}-08$ & 2.39E-09 \\
\hline U-232 & $1.50 \mathrm{E}-03$ & 2.01E-04 & $1.04 \mathrm{E}-03$ & $1.38 \mathrm{E}-04$ \\
\hline U-233 & $4.21 \mathrm{E}-05$ & 5.62E-06 & $2.90 \mathrm{E}-05$ & $3.87 \mathrm{E}-06$ \\
\hline U-234 & $1.36 \mathrm{E}-01$ & $1.81 \mathrm{E}-02$ & $9.41 \mathrm{E}-02$ & $1.25 \mathrm{E}-02$ \\
\hline U-235 & $5.71 \mathrm{E}-03$ & 7.61E-04 & 3.93E-03 & $5.24 \mathrm{E}-04$ \\
\hline U-236 & $4.60 \mathrm{E}-03$ & $6.13 \mathrm{E}-04$ & 3.17E-03 & 4.23E-04 \\
\hline U-237 & $3.33 \mathrm{E}-06$ & 4.44E-07 & $2.30 \mathrm{E}-06$ & 3.06E-07 \\
\hline U-238 & $3.66 \mathrm{E}-03$ & $4.88 \mathrm{E}-04$ & $2.53 \mathrm{E}-03$ & 3.37E-04 \\
\hline
\end{tabular}

A screening level analysis was made of the potential terrestrial biota dose using the soil concentrations ( $\mathrm{pCi} / \mathrm{g}$ ) in Table 4 and the RESRAD-BIOTA code (Version 1.8). Because RESRAD-BIOTA does not offer Mn54, Pu-240, U-232, U-236, and U-237 as input choices, these radionuclides were handled as follows:

1. Manganese-54 (Mn-54) concentrations were entered into RESRAD-BIOTA as cobalt-60 (Co-60). This is because Co-60 is a gamma-emitter like Mn-54 and the associated external, ingestion, and inhalation dose conversion factors (DCFs) published by the Environmental Protection Agency (https://www.epa.gov/radiation/federal-guidance-report-no-13-cd-supplement) exceed those of $\mathrm{Mn}-54$ by factors ranging from three to nine times. Thus the use of Co- 60 conservatively bounds the potential impact of Mn-54 on living organisms.

2. The plutonium-239 (Pu-239) and Pu-240 concentrations in Table 4 were summed and entered as Pu-239 in the code. This is acceptable because they are chemically similar, the time frame of 
interest is too short to be impacted by radioactive decay, and their DCFs for external exposure, ingestion, and inhalation are the same.

3. The uranium-236 (U-236) concentrations were added to the U-238 input for RESRAD-BIOTA. This was done because U-238 has similar enough DCFs to act as an analogue for U-236. The ingestion and inhalation DCFs are alike for both uranium isotopes. The external dose conversion factors are greater for U-236 but not large enough to impact the final results. The estimated doses in RESRAD-Biota are driven by internal irradiation and external doses are relatively minor.

4. Uranium-232 has no close analogue in the uranium series available in RESRAD-BIOTA. The radionuclide has a relatively short half-life of 68.9 years, and therefore the specific activity of ${ }^{232} \mathrm{U}$ is much higher than specific activity of the isotope ${ }^{238} \mathrm{U}$, which has a half-life of approximately 4.5 billion years. In addition the decay chain of ${ }^{232} \mathrm{U}$ produces very penetrating gamma rays. The most important gamma emitter, accounting for about 85 percent of the total dose from ${ }^{232} \mathrm{U}$ after 2 years, is thallium 208, which emits gamma rays of $2.6 \mathrm{MeV}$ that are very energetic and highly penetrating. Thorium-228 (with a half-life of 1.9 years) is the first daughter in the $\mathrm{U}-232$ decay chain. For this reason, the $\mathrm{U}-232$ concentrations were entered into the RESRAD-Biota code as Th-228.

5. Uranium-237 also has no close uranium analogue in RESRAD-BIOTA. The radionuclide's half-life (6.75 days) is shorter by many orders of magnitude than the other uranium isotopes. Because it decays quickly, the concentration in soil is also much lower (in most cases by orders of magnitude) than the other uranium isotopes. Finally, internal dose (inhalation and ingestion) DCFS for U-237 are orders of magnitude lower than for other uranium isotopes. For these reasons, it was concluded that $\mathrm{U}-237$ has little impact on the final dose calculations and therefore was not modelled in RESRAD-BIOTA.

The Level 1 screening analysis represents the most conservative estimate of impacts of contaminants in soil on terrestrial biota accessing the soil.

\subsection{Results and Conclusions}

Results of the Level 1 screening analyses are presented in Tables 5 and 6 . In each of the alternatives analyzed, the limiting organism is a terrestrial animal because the terrestrial animal analyses produced the highest summed concentration ratios. The Biota Concentration Guides (BCGS) were not exceeded in either scenario. The sum of the ratios of the soil concentration/BCG for all radionuclides were less than one, indicating that the biota dose limits of $1 \mathrm{rad} / \mathrm{d}(10 \mathrm{mGy} / \mathrm{d})$ for terrestrial plants and $0.1 \mathrm{rad} / \mathrm{d}$ (1 $\mathrm{mGy} / \mathrm{d}$ ) for terrestrial animals would not be approached if the HALEU project is conducted and either Alternative $1 \mathrm{a}$ or $1 \mathrm{~b}$ is used. No negative impact to plant or animal populations is expected and therefore no doses were calculated and a more detailed analysis was unnecessary. 
VFS-ID-ESER-NEPA-044-R1

October 27, 2018

Table 5. Results of Level 1 RESRAD-BIOTA analysis of proposed HALEU releases at MFC (Alternative 1a).

\begin{tabular}{|c|c|c|c|c|c|c|c|c|c|}
\hline \multicolumn{10}{|c|}{$\begin{array}{l}\text { Terrestrial BCG Report for Level } 1 \\
\text { Title: HALEU - MFC }\end{array}$} \\
\hline \multicolumn{10}{|c|}{$\begin{array}{l}\text { (Summed) Total Ratio for Limiting Organism: } 2.38 \mathrm{E}-01 \\
\text { (Summed) Water Ratio for Limiting Organism: } 0.00 \mathrm{E}+00 \\
\text { (Summed) Soil Ratio for Limiting Organism: } 2.38 \mathrm{E}-01\end{array}$} \\
\hline & \multicolumn{9}{|c|}{ Terrestrial Animal } \\
\hline & \multicolumn{4}{|c|}{ Water } & \multicolumn{4}{|l|}{ Soil } & TOTAL \\
\hline Nuclide $^{a}$ & $\begin{array}{c}\text { Concentration } \\
(\mathrm{pCi} / \mathrm{L})\end{array}$ & $\begin{array}{c}\text { BCG } \\
\text { (pCi/L) }\end{array}$ & Ratio & $\begin{array}{c}\text { Limiting } \\
\text { Organism }\end{array}$ & $\begin{array}{c}\text { Concentration } \\
(\mathrm{pCi} / \mathrm{g})\end{array}$ & $\begin{array}{c}\text { BCG } \\
(\mathrm{pCi} / \mathrm{g})\end{array}$ & Ratio & $\begin{array}{c}\text { Limiting } \\
\text { Organism }\end{array}$ & Ratio \\
\hline Am-241 & 0 & $2.02 \mathrm{E}+05$ & $0.00 \mathrm{E}+00$ & Yes & 0.388 & $3.89 \mathrm{E}+03$ & $9.96 \mathrm{E}-05$ & Yes & $9.96 \mathrm{E}-05$ \\
\hline Ce-144 & 0 & $2.85 \mathrm{E}+06$ & $0.00 \mathrm{E}+00$ & Yes & 0.000185 & $1.44 \mathrm{E}+03$ & $1.28 \mathrm{E}-07$ & Yes & $1.28 \mathrm{E}-07$ \\
\hline Co-60 & 0 & $1.19 \mathrm{E}+06$ & $0.00 E+00$ & Yes & 0.0217 & $6.92 \mathrm{E}+02$ & $3.14 \mathrm{E}-05$ & Yes & $3.14 \mathrm{E}-05$ \\
\hline Cs-134 & 0 & $3.26 \mathrm{E}+05$ & $0.00 \mathrm{E}+00$ & Yes & 0.0435 & $1.13 \mathrm{E}+01$ & 3.85E-03 & Yes & $3.85 \mathrm{E}-03$ \\
\hline Cs-135 & 0 & $7.79 \mathrm{E}+06$ & $0.00 \mathrm{E}+00$ & Yes & 0.00569 & $2.62 E+02$ & 2.17E-05 & Yes & $2.17 \mathrm{E}-05$ \\
\hline Cs-137 & 0 & $5.99 \mathrm{E}+05$ & $0.00 \mathrm{E}+00$ & Yes & 1.26 & $2.08 \mathrm{E}+01$ & 6.07E-02 & Yes & $6.07 \mathrm{E}-02$ \\
\hline Eu-154 & 0 & $2.17 \mathrm{E}+06$ & $0.00 \mathrm{E}+00$ & Yes & 0.102 & $1.29 \mathrm{E}+03$ & $7.90 \mathrm{E}-05$ & Yes & $7.90 \mathrm{E}-05$ \\
\hline Eu-155 & 0 & $2.71 \mathrm{E}+07$ & $0.00 \mathrm{E}+00$ & Yes & 0.172 & $1.58 \mathrm{E}+04$ & $1.09 \mathrm{E}-05$ & Yes & $1.09 \mathrm{E}-05$ \\
\hline Np-237 & 0 & $6.49 \mathrm{E}+06$ & $0.00 \mathrm{E}+00$ & Yes & 0.0000222 & $3.86 \mathrm{E}+03$ & $5.75 \mathrm{E}-09$ & Yes & $5.75 \mathrm{E}-09$ \\
\hline Pu-239 & 0 & $2.00 E+05$ & $0.00 E+00$ & Yes & 0.0106 & $6.11 \mathrm{E}+03$ & $1.73 \mathrm{E}-06$ & Yes & $1.73 \mathrm{E}-06$ \\
\hline Sb-125 & 0 & $6.97 E+06$ & $0.00 \mathrm{E}+00$ & Yes & 0.156 & $3.52 E+03$ & $4.43 \mathrm{E}-05$ & Yes & 4.43E-05 \\
\hline Sr-90 & 0 & $5.45 \mathrm{E}+04$ & $0.00 \mathrm{E}+00$ & Yes & 3.89 & $2.25 \mathrm{E}+01$ & $1.73 \mathrm{E}-01$ & Yes & $1.73 \mathrm{E}-01$ \\
\hline Tc-99 & 0 & $1.55 \mathrm{E}+07$ & $0.00 \mathrm{E}+00$ & Yes & 0.00000000346 & $4.49 E+03$ & $7.70 \mathrm{E}-13$ & Yes & $7.70 \mathrm{E}-13$ \\
\hline Th-228 & 0 & $6.33 \mathrm{E}+04$ & $0.00 \mathrm{E}+00$ & Yes & 0.000201 & $5.30 \mathrm{E}+02$ & 3.79E-07 & Yes & $3.79 \mathrm{E}-07$ \\
\hline $\mathrm{U}-233$ & 0 & $4.01 \mathrm{E}+05$ & $0.00 \mathrm{E}+00$ & Yes & 0.00000562 & $4.83 \mathrm{E}+03$ & $1.16 \mathrm{E}-09$ & Yes & $1.16 \mathrm{E}-09$ \\
\hline U-234 & 0 & $4.04 \mathrm{E}+05$ & $0.00 E+00$ & Yes & 0.0181 & $5.13 E+03$ & $3.53 \mathrm{E}-06$ & Yes & $3.53 \mathrm{E}-06$ \\
\hline U-235 & 0 & $4.19 E+05$ & $0.00 E+00$ & Yes & 0.000761 & $2.77 \mathrm{E}+03$ & $2.75 \mathrm{E}-07$ & Yes & $2.75 \mathrm{E}-07$ \\
\hline U-238 & 0 & $4.06 \mathrm{E}+05$ & $0.00 \mathrm{E}+00$ & Yes & 0.0011 & $1.58 \mathrm{E}+03$ & $6.97 \mathrm{E}-07$ & Yes & $6.97 \mathrm{E}-07$ \\
\hline \multirow[t]{3}{*}{ Summed } & - & - & $0.00 E+00$ & - & - & - & $2.38 \mathrm{E}-01$ & - & $2.38 \mathrm{E}-01$ \\
\hline & \multicolumn{9}{|c|}{ Terrestrial Plant } \\
\hline & \multicolumn{4}{|c|}{ Water } & \multicolumn{4}{|l|}{ Soil } & TOTAL \\
\hline Nuclide & $\begin{array}{c}\begin{array}{c}\text { Concentration } \\
(\mathrm{pCi} / \mathrm{L})\end{array} \\
\end{array}$ & $\begin{array}{c}\text { BCG } \\
\text { (pCi/L) }\end{array}$ & Ratio & $\begin{array}{c}\text { Limiting } \\
\text { Organism }\end{array}$ & $\begin{array}{c}\text { Concentration } \\
(\mathrm{pCi} / \mathrm{g})\end{array}$ & $\begin{array}{c}\text { BCG } \\
\text { (pCi/g) } \\
\end{array}$ & Ratio & $\begin{array}{c}\text { Limiting } \\
\text { Organism }\end{array}$ & Ratio \\
\hline Am-241 & 0 & $4.28 \mathrm{E}+07$ & $0.00 E+00$ & No & 0.00131 & $1.57 E+04$ & $8.33 \mathrm{E}-08$ & No & $8.33 \mathrm{E}-08$ \\
\hline Ce-144 & 0 & $2.90 \mathrm{E}+07$ & $0.00 \mathrm{E}+00$ & No & 0.000185 & $1.39 \mathrm{E}+04$ & $1.33 \mathrm{E}-08$ & No & $1.33 \mathrm{E}-08$ \\
\hline Co-60 & 0 & $1.49 \mathrm{E}+07$ & $0.00 \mathrm{E}+00$ & No & 0.0217 & $6.13 E+03$ & $3.54 \mathrm{E}-06$ & No & $3.54 \mathrm{E}-06$ \\
\hline Cs-134 & 0 & $2.28 \mathrm{E}+07$ & $0.00 \mathrm{E}+00$ & No & 0.0435 & $1.09 \mathrm{E}+03$ & 4.00E-05 & No & 4.00E-05 \\
\hline Cs-135 & 0 & $7.04 \mathrm{E}+08$ & $0.00 \mathrm{E}+00$ & No & 0.00569 & $2.81 \mathrm{E}+04$ & $2.02 \mathrm{E}-07$ & No & $2.02 \mathrm{E}-07$ \\
\hline Cs-137 & 0 & $4.93 \mathrm{E}+07$ & $0.00 \mathrm{E}+00$ & No & 1.26 & $2.21 \mathrm{E}+03$ & $5.71 \mathrm{E}-04$ & No & 5.71E-04 \\
\hline Eu-154 & 0 & $2.59 \mathrm{E}+07$ & $0.00 E+00$ & No & 0.102 & $1.25 \mathrm{E}+04$ & $8.18 \mathrm{E}-06$ & No & $8.18 \mathrm{E}-06$ \\
\hline Eu-155 & 0 & $3.18 \mathrm{E}+08$ & $0.00 \mathrm{E}+00$ & No & 0.172 & $1.53 \mathrm{E}+05$ & $1.13 \mathrm{E}-06$ & No & $1.13 \mathrm{E}-06$ \\
\hline Np-237 & 0 & $7.86 \mathrm{E}+07$ & $0.00 \mathrm{E}+00$ & No & 0.0000222 & $8.15 \mathrm{E}+03$ & $2.73 \mathrm{E}-09$ & No & $2.73 \mathrm{E}-09$ \\
\hline Pu-239 & 0 & $7.04 \mathrm{E}+09$ & $0.00 \mathrm{E}+00$ & No & 0.0106 & $1.27 \mathrm{E}+04$ & $8.36 \mathrm{E}-07$ & No & $8.36 \mathrm{E}-07$ \\
\hline Sb-125 & 0 & $7.04 \mathrm{E}+07$ & $0.00 \mathrm{E}+00$ & No & 0.156 & $3.49 \mathrm{E}+04$ & 4.47E-06 & No & 4.47E-06 \\
\hline Sr-90 & 0 & $3.52 \mathrm{E}+07$ & $0.00 \mathrm{E}+00$ & No & 3.89 & $3.58 \mathrm{E}+03$ & $1.09 \mathrm{E}-03$ & No & 1.09E-03 \\
\hline Tc-99 & 0 & $4.69 \mathrm{E}+08$ & $0.00 \mathrm{E}+00$ & No & 0.00000000346 & $2.19 \mathrm{E}+04$ & $1.58 \mathrm{E}-13$ & No & $1.58 \mathrm{E}-13$ \\
\hline Th-228 & 0 & $1.64 \mathrm{E}+07$ & $0.00 E+00$ & No & 0.000201 & $6.42 \mathrm{E}+03$ & 3.13E-08 & No & $3.13 \mathrm{E}-08$ \\
\hline U-233 & 0 & $1.06 \mathrm{E}+10$ & $0.00 E+00$ & No & 0.00000562 & $5.23 E+04$ & $1.07 \mathrm{E}-10$ & No & $1.07 \mathrm{E}-10$ \\
\hline U-234 & 0 & $3.08 \mathrm{E}+09$ & $0.00 \mathrm{E}+00$ & No & 0.0181 & $5.16 \mathrm{E}+04$ & $3.51 \mathrm{E}-07$ & No & $3.51 \mathrm{E}-07$ \\
\hline U-235 & 0 & $1.05 \mathrm{E}+08$ & $0.00 \mathrm{E}+00$ & No & 0.000761 & $2.74 \mathrm{E}+04$ & $2.77 \mathrm{E}-08$ & No & $2.77 \mathrm{E}-08$ \\
\hline U-238 & 0 & $4.28 \mathrm{E}+07$ & $0.00 \mathrm{E}+00$ & No & 0.0011 & $1.57 \mathrm{E}+04$ & 7.00E-08 & No & $7.00 \mathrm{E}-08$ \\
\hline Summed & - & - & $0.00 \mathrm{E}+00$ & - & - & - & $1.74 \mathrm{E}-03$ & - & $1.74 \mathrm{E}-03$ \\
\hline
\end{tabular}


VFS-ID-ESER-NEPA-044-R1

October 27, 2018

Table 6. Results of Level 1 RESRAD-BIOTA analysis of proposed HALEU releases at INTEC (Alternative 1b).

\begin{tabular}{|c|c|c|c|c|c|c|c|c|c|}
\hline $\begin{array}{l}\text { Terrestrial } \\
\text { Title: HALE }\end{array}$ & $\begin{array}{l}\text { CG Report for } \\
\text { - INTEC }\end{array}$ & & & & & & & & \\
\hline \multicolumn{10}{|c|}{$\begin{array}{l}\text { (Summed) Total Ratio for Limiting Organism: } 1.64 \mathrm{E}-01 \\
\text { (Summed) Water Ratio for Limiting Organism: } 0.00 \mathrm{E}+00 \\
\text { (Summed) Soil Ratio for Limiting Organism: } 1.64 \mathrm{E}-01\end{array}$} \\
\hline & \multicolumn{9}{|c|}{ Terrestrial Animal } \\
\hline & \multicolumn{4}{|c|}{ Water } & \multicolumn{4}{|c|}{ Soil } & TOTAL \\
\hline Am-241 & 0 & $2.02 E+05$ & $0.00 \mathrm{E}+00$ & Yes & 0.268 & $3.89 \mathrm{E}+03$ & $6.88 \mathrm{E}-05$ & Yes & $6.88 \mathrm{E}-05$ \\
\hline Ce-144 & 0 & $2.85 \mathrm{E}+06$ & $0.00 \mathrm{E}+00$ & Yes & 0.000127 & $1.44 \mathrm{E}+03$ & $8.81 \mathrm{E}-08$ & Yes & $8.81 \mathrm{E}-08$ \\
\hline Co-60 & 0 & $1.19 \mathrm{E}+06$ & $0.00 \mathrm{E}+00$ & Yes & 0.0149 & $6.92 \mathrm{E}+02$ & $2.15 \mathrm{E}-05$ & Yes & $2.15 \mathrm{E}-05$ \\
\hline Cs-134 & 0 & $3.26 \mathrm{E}+05$ & $0.00 \mathrm{E}+00$ & Yes & 0.03 & $1.13 \mathrm{E}+01$ & $2.66 \mathrm{E}-03$ & Yes & $2.66 \mathrm{E}-03$ \\
\hline Cs-135 & 0 & $7.79 E+06$ & $0.00 \mathrm{E}+00$ & Yes & 0.00292 & $2.62 \mathrm{E}+02$ & $1.12 \mathrm{E}-05$ & Yes & $1.12 \mathrm{E}-05$ \\
\hline Cs-137 & 0 & $5.99 E+05$ & $0.00 \mathrm{E}+00$ & Yes & 0.872 & $2.08 \mathrm{E}+01$ & $4.20 \mathrm{E}-02$ & Yes & $4.20 \mathrm{E}-02$ \\
\hline Sb-125 & 0 & $6.97 \mathrm{E}+06$ & $0.00 \mathrm{E}+00$ & Yes & 0.107 & $3.52 \mathrm{E}+03$ & $3.04 \mathrm{E}-05$ & Yes & 3.04E-05 \\
\hline Sr-90 & 0 & $5.45 \mathrm{E}+04$ & $0.00 \mathrm{E}+00$ & Yes & 2.68 & $2.25 \mathrm{E}+01$ & 1.19E-01 & Yes & 1.19E-01 \\
\hline Tc-99 & 0 & $1.55 \mathrm{E}+07$ & $0.00 \mathrm{E}+00$ & Yes & 0.00000000239 & $4.49 \mathrm{E}+03$ & $5.32 \mathrm{E}-13$ & Yes & $5.32 \mathrm{E}-13$ \\
\hline Th-228 & 0 & $6.33 \mathrm{E}+04$ & $0.00 \mathrm{E}+00$ & Yes & 0.000138 & $5.30 \mathrm{E}+02$ & $2.60 \mathrm{E}-07$ & Yes & $2.60 \mathrm{E}-07$ \\
\hline U-233 & 0 & $4.01 \mathrm{E}+05$ & $0.00 \mathrm{E}+00$ & Yes & 0.00000387 & $4.83 \mathrm{E}+03$ & $8.02 \mathrm{E}-10$ & Yes & $8.02 \mathrm{E}-10$ \\
\hline U-234 & 0 & $4.04 \mathrm{E}+05$ & $0.00 \mathrm{E}+00$ & Yes & 0.0125 & $5.13 E+03$ & $2.44 \mathrm{E}-06$ & Yes & $2.44 \mathrm{E}-06$ \\
\hline U-235 & 0 & $4.19 \mathrm{E}+05$ & $0.00 \mathrm{E}+00$ & Yes & 0.000524 & $2.77 \mathrm{E}+03$ & $1.89 \mathrm{E}-07$ & Yes & $1.89 \mathrm{E}-07$ \\
\hline $\mathrm{U}-238$ & 0 & $4.06 \mathrm{E}+05$ & $0.00 \mathrm{E}+00$ & Yes & 0.00076 & $1.58 \mathrm{E}+03$ & $4.82 \mathrm{E}-07$ & Yes & $4.82 \mathrm{E}-07$ \\
\hline \multirow[t]{3}{*}{ Summed } & - & - & $0.00 \mathrm{E}+00$ & - & - & - & $1.64 \mathrm{E}-01$ & - & $1.64 \mathrm{E}-01$ \\
\hline & \multicolumn{9}{|c|}{ Terrestrial Plant } \\
\hline & \multicolumn{4}{|c|}{ Water } & \multicolumn{4}{|c|}{ Soil } & TOTAL \\
\hline Eu-154 & 0 & $2.59 \mathrm{E}+07$ & $0.00 \mathrm{E}+00$ & No & 0.0703 & $1.25 \mathrm{E}+04$ & $5.64 \mathrm{E}-06$ & No & $5.64 \mathrm{E}-06$ \\
\hline Eu-155 & 0 & $3.18 \mathrm{E}+08$ & $0.00 \mathrm{E}+00$ & No & 0.0118 & $1.53 \mathrm{E}+05$ & $7.72 \mathrm{E}-08$ & No & $7.72 \mathrm{E}-08$ \\
\hline Np-237 & 0 & $7.86 \mathrm{E}+07$ & $0.00 \mathrm{E}+00$ & No & 0.0000153 & $8.15 E+03$ & $1.88 \mathrm{E}-09$ & No & $1.88 \mathrm{E}-09$ \\
\hline Pu-239 & 0 & $7.04 \mathrm{E}+09$ & $0.00 \mathrm{E}+00$ & No & 0.00729 & $1.27 \mathrm{E}+04$ & $5.75 \mathrm{E}-07$ & No & $5.75 \mathrm{E}-07$ \\
\hline Sb-125 & 0 & $7.04 \mathrm{E}+07$ & $0.00 \mathrm{E}+00$ & No & 0.107 & $3.49 \mathrm{E}+04$ & $3.07 \mathrm{E}-06$ & No & $3.07 \mathrm{E}-06$ \\
\hline Sr-90 & 0 & $3.52 \mathrm{E}+07$ & $0.00 \mathrm{E}+00$ & No & 2.68 & $3.58 \mathrm{E}+03$ & $7.49 \mathrm{E}-04$ & No & 7.49E-04 \\
\hline Tc-99 & 0 & $4.69 E+08$ & $0.00 \mathrm{E}+00$ & No & 0.00000000239 & $2.19 \mathrm{E}+04$ & $1.09 \mathrm{E}-13$ & No & $1.09 \mathrm{E}-13$ \\
\hline Th-228 & 0 & $1.64 \mathrm{E}+07$ & $0.00 \mathrm{E}+00$ & No & 0.000138 & $6.42 \mathrm{E}+03$ & $2.15 \mathrm{E}-08$ & No & $2.15 \mathrm{E}-08$ \\
\hline U-233 & 0 & $1.06 \mathrm{E}+10$ & $0.00 \mathrm{E}+00$ & No & 0.00000387 & $5.23 \mathrm{E}+04$ & 7.40E-11 & No & $7.40 \mathrm{E}-11$ \\
\hline U-234 & 0 & $3.08 \mathrm{E}+09$ & $0.00 \mathrm{E}+00$ & No & 0.0125 & $5.16 \mathrm{E}+04$ & $2.42 \mathrm{E}-07$ & No & $2.42 \mathrm{E}-07$ \\
\hline U-235 & 0 & $1.05 \mathrm{E}+08$ & $0.00 \mathrm{E}+00$ & No & 0.000524 & $2.74 \mathrm{E}+04$ & $1.91 \mathrm{E}-08$ & No & $1.91 \mathrm{E}-08$ \\
\hline $\mathrm{U}-238$ & 0 & $4.28 \mathrm{E}+07$ & $0.00 \mathrm{E}+00$ & No & 0.00076 & $1.57 \mathrm{E}+04$ & $4.83 \mathrm{E}-08$ & No & $4.83 \mathrm{E}-08$ \\
\hline Summed & - & - & $0.00 \mathrm{E}+00$ & - & - & - & $1.20 \mathrm{E}-03$ & - & $1.20 \mathrm{E}-03$ \\
\hline
\end{tabular}

